\title{
URGENSI INOVASI PENDIDIKAN ISLAM: MENYATUKAN DIKOTOMI PENDIDIKAN
}

\author{
Naif \\ Sekolah Tinggi Ilmu Tarbiyah Muslim Asia Afrika Jakarta \\ JL. Pendidikan Gg. Asia - Afrika, No. 78 K, Ciputat, 15122 \\ Email: naifadnan@ymail.com
}

\begin{abstract}
The Urgency of the Innovation of Islamic Education: Uniting Education Dichotomy. Education is one of the most important factors in the development effort of a country. Education is the way to develop students' potential, whether it is physically, creatively or intentionally in order it becomes real and useful for life. History records that the country which has a high concern to the education will be more advanced than other countries that put aside the problem of education. However, a great concern from the country only is not enough. Practitioners and academics should strive hard to do persistent innovation in managing and developing the education. The innovation should be based on the purpose of the education to improve the quality of the education, which will ultimately educate the nation and produce competitive and dignified human being.
\end{abstract}

Keywords: Innovation, Urgency, Dichotomy

\begin{abstract}
Abstrak: Urgensi Inovasi Pendidikan Islam: Menyatukan Dikotomi Pendidikan. Pendidikan adalah salah satu faktor terpenting dalam usaha pembangunan yang dilakukan oleh sebuah negara. Pendidikan merupakan upaya pengembangan potensi manusiawi dari para peserta didik, baik berupa fisik, cipta maupun karsa agar potensi tersebut menjadi nyata dan dapat berfungsi bagi perjalan kehidupan. Sejarah mencatat bahwa Negara yang memiliki perhatian yang tinggi pada dunia pendidikan, maka negara tersebut akan mengalami kemajuan yang lebih tinggi dibandingkan dengan negara lain yang menomorduakan masalah pendidikan. Namun, perhatian yang besar dari negara saja tidaklah cukup,karena praktisi dan akademisi harus berupaya keras untuk melakukan inovasi tiada henti dalam mengelola dan mengembangkan pendidikan, inovasi pendidikan tersebut haruslah didasarkan pada tujuan pendidikan guna meningkatkan kualitas pendidikan, yang pada akhirnya akan mencerdaskan kehidupan bangsa dan membentuk insan yang kompetitif dan bermartabat.
\end{abstract}

Kata kunci: Inovasi, Urgensi, Dikotomi 


\section{Pendahuluan}

Pada saat sekarang ini, umat Islam mulai menyadari bahwa mereka tidak mungkin berkompetisi dengan kekuatan yang menantang kepada pihak Barat, Imperialisme modern dan misionaris Kristen, apabila mereka terus melanjutkan kegiatan dengan cara-cara tradisional dalam menegakkan Islam.Oleh karena itu, umat Islam tak akan terlepas dengan mengeksplorasi segala sumber daya yang dimilikinya. Dengan cara mencurahkan segala daya dan kemampuanya untuk selalu berinovasi, menemukan sesuatu yang baru dapat membantu hidupnya menjadi lebih baik. Jika umat Islam di Indonesia tidak menggali segala kemampuanya maka ia akan tertinggal bahkan tergerus oleh zaman yang selalu berkembang.

Inovasi didefinisikan sebagai suatu ide, praktek atau obyek yang dianggap sebagai sesuatu yang baru oleh seorang individu, sehingga inovasi tersebut dapat dipandang sebagai suatu upaya untuk mencapai tujuan tertentu. Sedangkan Menurut Santoso S. Hamijoyo, inovasi pendidikan adalah suatu perubahan baru yang berbeda dari hal sebelumnya, dan sengaja diusahakan untuk meningkatkan kemampuan guna mencapai suatu tujuan dalam dunia pendidikan. ${ }^{1}$ Sehingga inovasi pendidikan dapat dikatakan sebagai sebuah usaha untuk mengadakan suatu perubahan dengan tujuan untuk memperoleh hal yang lebih baik dalam bidang pendidikan. $^{2}$

Inovasi pendidikan dilakukan untuk memecahkan masalah-masalah kependidikan. Jadi, inovasi pendidikan adalah suatu ide, barang, metode, yang dirasakan atau diamati sebagai hal yang baru bagi hasil seseorang atau kelompok orang (masyarakat), baik berupa hasil inversi (penemuan baru) atau discoveri (baru ditemukan orang), yang digunakan untuk mencapai tujuan pendidikan atau untuk memecahkan masalah pendidikan. ${ }^{3}$ Namun dalam konteks pendidikan, inovasi dapat berjalan dengan baik dan akan menghasilkan suatu hal yang positif dan lebih baik, jika para praktisi pendidikan memahami beberapa karakteristik dari inovasi pendidikan tersebut, karena karakteristik inovasi pendidikan tersebut merupakan sifat yang melekat pada diri inovasi pendidikan itu sendiri.

${ }^{1}$ Burhanuddin Salam, Pengantar Pedagogik (Dasar-Dasar Ilmu Mendidik), (Jakarta: Rineka Cipta, 1997), h. 179.

${ }^{2}$ Udin Syaefudin Sa’ud, Inovasi Pendidikan (Bandung: Alvabeta, 2010), h.8

${ }^{3}$ FuadIhsan, DasarDasarPendidikan, (Jakarta, RinekaCipta, 1995), hal 192 


\section{Penyebab Lahirnya Inovasi Pendidikan Islam}

Kejayaan Islam dalam ilmu pengetahuan mengalami kemunduran setelah kota Baghdad yang merupakan pusat ilmu pengetahuan dihancurkan oleh tentara Mongol pada tahun 1258. Meskipun kejayaan Islam masih berlanjut hingga berakhirnya Turki Ustmani, namun dalam bidang ilmu pengetahuan umat Islam mengalami kemunduran, karena umat Islam ketika itu kurang tertarik kepada sains, sebagaimana umat Islam pada masa sebelumnya.

Umat Islam mulai sadar akan ketertinggalannya dari dunia Barat pada sekitar abad ke-19. Negara Islam di bagian Barat dan Timur membuka mata umat Islam untuk menyaingi Barat. Dengan demikian, jelaslah bahwa penyebab lahirnya inovasi dalam pendidikan Islam bukan akibat adanya pertentangan antara kaum agama dan ilmuwan sebagaimana dalam agama Kristen, melainkan karena adanya perasaan tertinggal dari kemajuan dunia Barat.

Kemajuan ilmu pengetahuan dan teknologi yang dicapai Barat telah menggeser pandangan hidup manusia serta melahirkan terma-terma baru, seperti nasionalisme dan pendidikan. Pendidikan merupakan sarana paling penting bukan hanya sebagai wahana konservasi dalam arti tempat pemeliharaan, pelestarian, penanaman, dan pewarisan nilai-nilai dari tradisi suatu masyarakat, tetapi juga sebagai sarana kreasi yang dapat menciptakan, mengembangkan dan mentransfornasikan umat ke arah pembentukan budaya baru. Oleh karena itu, tokoh-tokoh pembaharuan Islam banyak menggunakan pendidikan Islam, baik yang bersifat formal, non-formal, untuk menyadarkan umat kembali kepada kejayaan Islam seperti masa lampau.

\section{Urgensi inovasi pendidikan}

Implementasi inovasi pendidikan merupakan sebuah upaya untuk meningkatkan kemampuan dari berbagai sumber komponen pendidikan, seperti: a) tenaga kependidikan, b) sarana dan prasarana pendidikan, serta 3) sistem dan konsep dalam pelaksanaan kegiatan pendidikan. Artinya keseluruhan sistem yang terkait dengan pendidikan perlu untuk ditingkatkan agar semua tujuan yang direncanakan dapat dicapai dengan sebaik-baiknya.

Kompleksnya permasalahan pendidikan yang dialami oleh pola 
pelaksanaan pendidikan di negeri ini, menuntut kita untuk merespon untuk melakukan suatu kegiatan tindakan prefentif, persuasive dan inovatif. Walaupun sesuatu yang baru belum tentu baik, artinya adanya inovasi belum tentu inovatif, kreatif, apalagi relevansinya dengan situasi dan kondisi, ${ }^{4}$ sehingga dapat dikatakan bahwa inovasi pendidikan dilakukan sebagai suatu problem solving dari berbagai macam problematika pendidikan yang dihadapi. Secara sederhana, masalah pendidikan yang harus menuntut suatu inovasi.

Dari kelompok problematika pendidikan tersebut, maka langkah yang cukup sederhana untuk melakukan suatu inovasi pendidikan tersebut adalah sebagai berikut: a) Melakukan pemerataan pelayanan pendidikan, b) Melakukan peningkatan mutu pendidikan, c) Melakukan inovasi untuk lebih menyerasikan kegiatan belajar dengan tujuan pendidikan, d) Berusaha untuk lebih melakukan efisiensi pendidikan, baik dari sisi ekonomi, waktu dan lain sebagainya, e) Menyempurnakan sistem informasi pendidikan, f) Menumbuhkan masyarakat yang gemar belajar, g) Tersebarnya paket pendidikan yang memikat, mudah dicerna, dan mudah diperoleh, h) Meluasnya kesempatan kerja dan lain sebagainya. $^{5}$

Inovasi-inovasi pendidikan tersebut dapat berfungsi sebagai arah baru dalam dunia kependidikan yang berfungsi sebagai alternatif untuk memecahkan masalah pendidikan yang belum dapat diatasi dengan cara konvensional secara tuntas. Secara lebih rinci tentang maksudmaksud diadakannya inovasi pendidikan ini adalah sebagai berikut: (1) Pembaruan pendidikan sebagai tanggapan baru terhadap masalah pendidikan. Majunya bidang tekhnologi dan komunikasi sekarang ini dapat memberikan pengaruh positif terhadap kemajuan di bidang lain, termasuk dalam dunia pendidikan. Tugas inovator pendidikan yang terutama adalah memecahkan masalah yang dijumpai dalam dunia pendidikan, baik dengan cara yang konvensional maupun dengan cara yang inovatif. Inovasi atau pembaruan pendidikan juga merupakan suatu tanggapan baru terhadap masalah kependidikanyang nyata dihadapi.

${ }^{4}$ Hasbullah, Dasar-dasar Ilmu Pendidikan (Umum dan Agama Islam) (Jakarta: RajawaliPers, 2009), h. 190.

${ }^{5}$ Burhanuddin Salam, Pengantar Pedagogik (Dasar-Dasar Ilmu Mendidik), (Jakarta: Rineka Cipta, 1997), h. 179 
Titik pangkal pembaruan pendidikan adalah masalah pendidikan yang aktual, yang secara sistematis akan dipecahkan dengan cara inovatif. (2) Inovasi pendidikan sebagai upaya untuk mengembangkan pendekatan yang lebih efektif dan ekonomis. Inovasi pendidikan dilakukan dalam upaya "problem solving" yang dihadapi dunia pendidikan yang selalu dinamis dan berkembang.Adapun sifat pendekatan yang diperlukan untuk pemecahan masalah pendidikan yang kompleks dan berkembang itu harus berorientasi kepada halhal yang efektif dan murah, serta peka terhadap timbulnya masalah baru di dalam pendidikan. ${ }^{6}$

\section{Model-model Inovasi Pendidikan}

Diskursus tentang pendidikan, setidaknya akan mencakup dua elemen yang cukup pendasar, yaitu elemen teori dan elemen praktek. ${ }^{7}$ Termasuk juga inovasi pendidikan.Pembaharuan dalam hal ini menunjukkan suatu proses yang membuat suatu objek, ide, atau praktek baru yang muncul untuk kemudian diserap oleh seseorang, kelompok, organisasi pendidikan. Proses ini mempunyai beberapa tahapan yang akan jelas terlihat bila digambarkan dengan suatu kontinum sebagai berikut:

1. Invention (Penemuan).

Invention meliputi penemuan atau penciptaan tentang suatu hal yang baru. Akan tetapi pembaharuan yang terjadi dalam pendidikan terkadang menggambarkan suatu hasil yang sangat berbeda dengan yang terjadi sebelumnya. Tempat terjadinya invention biasanya di dalam maupun diluar sekolah kebanyakan pembaharuan dari tipe hardware berasal dari luar sekolahsebaliknya, banyak "invention" terjadi di dalam sekolah ketika para guru berupaya untuk mengubah situasi atau menciptakan cara baru untuk memecahkan cara lama.

2. Development (Pengembangan).

Pembaharuan biasanya harus mengalami suatu pengembangan, dan belum bisa masuk ke dalam dimensi skala besar. "Development" sering

${ }^{6}$ Hasbullah, Dasar-dasar Ilmu Pendidikan (Umum dan Agama Islam) (Jakarta: RajawaliPers, 2009), h. 201.

${ }^{7}$ Laine B Johnson, Contexual Teaching \& Learning - Menjadikan Kegiatan BelajarMengajar Mengasyikkan dan Bermakna, (Bandung: MLC, 2007), h. 17. 
sekali bergandengan dengan riset sehingga prosedur research dan development meliputi berbagai aktivitas, antara lain riset dasar, seperti pencarian dan pengujian teori-teori belajar. Riset ini mengetengahkan proses pengembangan kurikulum oleh paratim ahli penulis program kurikulum, sekolah percobaan tempat bahan disiapkan untuk diuji cobakan, dan desain riset valuatif dibuat untuk menilai keefektifan berbagai pembaharuan kurikulum.

3. Diffusion (Penyebaran).

Konsep diffusion seringkali digunakan secara sinonim dengan konsep dissemination, akan tetapi disini diberikan dengan konotasi yang juga berbeda. Definisi diffusion menurut Roger adalah "persebaran suatu ide baru dari sumber inventationnya kepada pemakai atau penyerap yang terakhir". Kalau istilah diffusion adalah netral dan betul memaksudkan persebaran suatu pembaharuan, dissemination digunakan disini untuk menunjukkan suatu pola difusi yang terencana, yang didalamnya beberapa biro (agency) mengambil langkah khusus untuk menjamin agar suatu pembaharuan akan mencapai jumlah paling banyak. ${ }^{8}$

\section{Karakteristik Inovasi Pendidikan}

Vanterpool mengatakan bahwa karakteristik inovasi pendidikan yang memprediksikan kemungkinan besar akan sukses adalah berikut: (a) Relative advantage, artinya relatif berguna dibandingkan dengan yang telah ada sebelumnya. (b) Compatibility, artinya apakah inovasi tersebut akan konsisten terhadap nilai-nilai, pengalaman dan kebutuhan para adopter. (c) Testability, artinya seberapa jauh inovasi tersebut bisa diujicobakan di sekolah-sekolah atau di lembaga pendidikan. (d) Observability, artinya apakah inovasi tersebut dapat diperlihatkan secara nyata hasilnya kepada para peserta didik dan Apakah kita bisa melihat variasi-variasi saat mengaplikasikan inovasi tersebut. (e) Complexity, artinya apakah guru-guru memerlukan pelatihan untuk mengaplikasikan inovasi tersebut dan apakah akan menambah tugas kerja guru. ${ }^{9}$

\footnotetext{
${ }^{8}$ Cece Wijaya, UpayaPembahruan dalam Pendidikan Dan Pengajaran (Bandung: Remaja Rosdakarya, 1992), h. 10

${ }^{9}$ UdinSyaefudin Sa’ud,Inovasi Pendidikan, (Bandung: Alfabeta, 2012)
} 
Sedangkan menurut Everett M. Rogers mengemukakan bahwa karakteristik inovasi yang dapat mempengaruhi cepat atau lambatnya penerimaan suatu inovasi adalah sebagai berikut:(a)Keunggulan relatif, yaitu sejauh mana inovasi dapat memberikan manfaat atau keuntungan, bagi penerimanya, yang dapat diukur berdasarkan nilai ekonominya, prestise sosial, kenyamanan, kepuasaan dan lainnya. (b)Konfirmanilitas atau kompatibel (compatibility), yaitu tingkat kesesuaian inovasi dengan nilai (value), pengalaman lalu, dan kebutuhan dari penerima. (c) Kompleksitas (complexity), yaitu tingkat kesukaran atau kerumitan untuk memahami dan menggunakan inovasi bagi penerima. (d) Trialabilitas (trialability), yaitu dapat dicoba atau tidaknya suatu inovasi oleh penerima. (e) Dapat diamati (observability) yaitu mudah atau tidaknya diamati suatu hasil inovasi. Suatu inovasi yang hasilnya mudah diamati akanmakin cepat diterima oleh masyarakat. Adapun beberapa kemampuan bidang yang dapat diamati, diantaranya: 1) manajemen pendidikan, 2) metodologi pengajaran, 3) media pembelajaran, 4) sumber belajar, 5) pelatihan guru, 6) implementasi kurikulum,dll.

Dari kelima karakteristik tersebut didapat peta konsep sebagai berikut: a) Keunggulan reatif, manfaat, menguntungkan pengguna, ekonomis, kepuasan pengguna, b) Kompleksitas, kerumitan, tingkat kesulitan, c) Kompatibilitas, kesesuaian dengan nilai, kesesuaian dengan pengalaman, kesesuaian dengan kebutuhan, d) Trialabilitas, dapat diuji coba, bergerak dan fakta. e) Observability, dapat diamati, terlihat, dapat dirasakan.

\section{Urgensi Karakteristik Inovasi pendidikan}

Setiap orang atau individu dalam pendidikan hendaknya berperan untuk melakukan suatu inovasi dalam pendidikan, karena prestasi pendidikan tergantung dari prestasi individu dalam melakukan suatu inovasi pendidikan. Prestasi individu dalam pendidikan merupakan bagian dari prestasi pendidikan yang pada gilirannya merupakan prestasi organisasi pendidikan. Karena itu, unsur di dalam dunia pendidikan, baik guru maupun yang terlibat dalam proses pendidikan harus mempunyai niat dan perhatian serta konsistensi yang terintegrasi dan berkesinambungan. Semua pihak yang berperan serta dalam proses inovasi pendidikan harus mengetahui tujuan, sasaran dan perencanaan maupun strategi inovasi yang dipergunakan dalam melakukan kegiatan inovasi pendidikan, sehingga hasilnya dapat memenuhi harapan dalam 
pendidikan. Melakukan kegiatan inovasi pendidikan merupakan tugas yang tidak ringan, terutama bagi penyelenggara kegiatan pendidikan. Di sini dibutuhkan manajemen pendidikan yang baik dan strategi pelaksanaan yang inovatif dan juga baik agar organisasi pendidikan mampu menghasilkan SDM yang berkualitas dan kegiatan pendidikan akan termasuk kepada katagori yang berhasil. ${ }^{10}$

Dalam bidang pendidikan, banyak usaha yang dilakukan untuk kegiatan yang sifatnya inovatif, inovasi yang terjadi dalam bidang pendidikan tersebut, antara lain dalam hal 1) manajemen pendidikan, 2) metodologi pengajaran, 3) media, 4) sumber belajar, 5) pelatihan guru, 6) implementasi kurikulum dan lain sebagainya.

Pentingnya implementasi inovasi pendidikan antara lain: (a) Mengejar ketinggalan yang dihasilkan oleh kemajuan ilmu dan teknologi, sehingga makin lama pendidikan maka semakin berjalan sejajar dengan kemjuan tersebut, (b) Mengusahakan terselenggaranya pendidikan sekolah maupun luar sekolah bagi setiap warga Negara. Misalnya meningkatkan daya tampung usia sekolah SD, SLTP, SLTA, dan Perguruan Tinggi. (c) Inovasi pendidikan dapat berupa1) Menciptakan pengetahuan baru, 2) Memandu arah proses pencarian penyedia dan pengguna teknologi,4) Memasok atau menyediakan sumber daya, yang berupa modal, kompetensi dan sumber daya lainnya, 5) Memfasilitasi penciptaan ekonomi eksternal yang positif (dalam bentuk pertukaran informasi, pengetahuan dan visi), 6) Memfasilitasi formasi pasar. (d) Pembinaan personalia. Inovasi yang sesuai dengan komponen personel misalnya: peningkatan mutu guru, sistem kenaikan pangkat, aturan tata tertib siswa, dan sebagainya. (e) Banyaknya personal dan wilayah kerja. Inovasi pendidikan yang relevan dengan aspek ini misalnya: berapa ratio guru siswa pada satu sekolah dalam sistem pamong. (f) Fasilitas fisik. Inovasi pendidikan yang sesuai dengan komponen pendidikan, (g) Penggunaan waktu. Inovasi yang relevan dengan komponen ini seperti pengaturan waktu belajar (semester, catur wulan, pembuatan jadwal pelajaran yang dapat memberi kesempatan

10 Untuk kriteriakeberhasilan suatu pendidikan tersebut menurut Made Pidarta dapat dicirikan sebagai berkut: 1) siswa memiliki sikap belajar, 2) tahu tentang cara belajar, 3) memiliki rasa percaya diri, 4) mencintai prestaasi yang tinggi, 5) memiliki etos kerja, 6) Kreatif dan produktif, 7) puas akan sukses yang dicapai. Lihat di Made Pidarta, Landasan Kependidikan, (Jakarta: PT Rineka Cipta, 2000), h. 233-234 
siswa untuk memilih waktu sesuai dengan keperluannya, dan sebagainya. (h) Perumusan tujuan. (i) Strategi. Yang dimaksud dengan strategi dalam hal ini ialah tahap kegiatan yang dilaksanakan untuk mencapai tujuan inovasi pendidikan.

Adapun macam dan pola strategi yang digunakan sangat sukar untuk diklasifikasikan, tetapi secara kronologis biasanya menggunakan pola urutan sebagai berikut: (1) Desain. Ditemukannya suatu inovasi dengan perencanaan penyebarannya berdasarkan suatu penelitian dan obeservasi atau hasil penilaian terhadap pelaksanaan sistem pendidikan yang sudah ada. (2) Kesadaran dan perhatian. Suatu potensi yang sangat menunjang berhasilnya inovasi ialah adanya kesadaran dan perhatian sasaran inovasi (baik individu maupun kelompok) akan perlunya inovasi. Berdasarkan kesadaran itu mereka akan berusaha mencari informasi tentang inovasi. (3) Evaluasi. Para sasaran inovasi mengadakan penilaian terhadap inovasi tentang kemampuannya untuk mencapai tujuan, tentang kemungkinan dapat terlaksananya sesuai dengan kondisi situasi, pembiayaannya dan sebagainya. (4)Percobaan. Para sasaran inovasi mencoba menerapkan inovasi untuk membuktikan apakah memang benar inovasi yang dinilai baik itu dapat diterapkan seperti yang diharapkan. Jika ternyata berhasil maka inovasi akan diterima dan terlaksana dengan sempurna sesuai strategi inovasi yang telah direncanakan.

\section{Faktor yang dapat dijadikan pertimbangan dalam pelaksanaan inovasi pendidikan}

Sedikitnya terdapat beberapa faktor yang dapat dijadikan pertimbangan dalam pelaksanaan suatu inovasi pendidikan, bahkan menurut Zaltam dan Holbek untuk memperjelas inovasi dengan cepat lambatnya proses penerimaan diantaranya adalah:

a. Pembiayaan, Pembiayaan menentukan cepat lambatnya penerimaan masyarakat atas program inovasi. Biaya itu sendiri tergantung pada kualitas inovasi yang diajukan.

b. Balik modal. Di dalam inovasi pendidikan atribut ini sukar dipertimbangkan, karena pada intinya pendidikan merupakan investasi jangka panjang melalui pengorbanan langsung dan tidak langsung sebagaimana terdapat dalam teori pembiayaan pendidikan. Balik modal hanya berlaku pada inovasi perusahaan. 
c. Efesiensi, inovasi pendidikan harus mencerminkan efisiensi, baik waktu maupun biaya.

d. Resiko dari ketidakpastian, jika resiko yang ditimbulkan kecil, maka program akan cepat diterima.

e. Mudah dikomunikasikan, inovasi akan cepat diterima jika mudah dikomunikasikan.

f. Kompatibilitas, artinya konsisten dengan nilai-nilai yang berlaku di masyarakat.

g. Kompleksitas, artinya mudah untuk dipelajari dan dipahami.

h. Status ilmiah, kadar ilmiah yang dimiliki sebuah inovasi akan cepat diterima dari pada yang tidak memiliki kadar ilmiah.

i. Kadar keaslian, Ini artinya inovasi diluncurkan dalam bentuknya sebagai sesuatu yang asli, tidak meniru, bukan jiplakan.

j. Dapat dilihat kemanfaatannya, artinya manfaat dari inovasi itu jelas, mudah dilihat, dan mudah dipahami, sehingga mudak pula untuk dilaksanakan.

k. Dapat dilihat batas sebelumnya, inovasi akan dapat diterima jika batasbatas sebelumnya jelas terlihat.

1. Keterlibatan sasaran perubahan, inovasi akan mudah diterima jika warga masyarakat diikutsertakan dalam proses yang dijalankan.

m. Hubungan interpersonal, inovasi membutuhkan adanya hubungan antar semua persenil yang terlibat. Saling memberitahu dan saling mempengaruhi.

n. Kepentingan umum atau pribadi,

o. Penyuluhan inovasi. Dengan atribut tersebut para pendidik dapat menganalisis inovasi pendidikan yang sedang disebarluaskan, sehingga dapat memanfaatkan hasil analisisnya untuk membantu mempercepat proses penerimaan inovasi tersebut.

Inovasi Pendidikan Islam merupakan suatu perubahan atau pembaharuan yang dilakukan menuju kondisi yang lebih baik untuk tercapainya tujuan pendidikan yang dicita-citakan yaitu pendidikan yang selaras dengan nilai-nilai luhur agama Islam. 


\section{Dasar dan Tujuan Inovasi Pendidikan Islam}

Dasar adalah pangkal tolak dari suatua ktivitas atau landasan tempat berpijak atas tegaknya sesuatu. Dasar pelaksanaan pendidikan Islam adalah:

\section{Al-Qur'an}

Islam adalah agama yang membawa misi agar umatnya menyelenggarakan pendidikan dan pengajaran. Ayat al-Qur'an yang pertama kali turun adalah berkenaan dengan masalah keimanan juga masalahp endidikan (QS. Al Alaq: 1-5). Dari aya ttersebut di atas dapatlah disimpulkan bahwa seolah-olah Tuhan berkata hendaknya manusia meyakini akan adanya Tuhan Pencipta manusia (dari segumpal darah), selanjutnya untuk memperkokoh keyakinannya dan memeliharanya agar tidak luntur hendaknya melaksanakan pendidikan dan pengajaran.

Selain surat Al-Alaq ayat 1-5 sebagai dasar pelaksanaan pendidikan, masih banyak ayat al-Qur'an yang dapat dijadikan sebagai dasar dalam pendidikan Islam yaitu Surat Al-Baqarah ayat 31. Ayat ini menjelaskan manusia dapat dididik atau menerima pengajaran, karena untuk memahami segala sesuatu belum cukup kalau memahami apa, bagaimana serta manfaat benda itu tetapi harus memahami sampai pada hakikat benda itu.

Surat Al-A'rof ayat 179 adalah ayat yang menjelaskan bahwa kita harus berfikir kritis dengan menggunakan pancaindra yang telah diberikan oleh Allah. Oleh karena itu, Pendidikan Islam sangat berperan untuk mengarahkan cara berfikir kita agar dapat berfikir secara kritis untuk mengembangkan ilmu pengetahuan. ${ }^{11}$ Surat Al Hasyrayat 18 adalahAyat yang menjelaskan bahwa Allah memperingatkan orang-orang yang beriman agar menatap masa depan. Dengan melakukan berbagai inovasi maka kita bisa mengembangkan berbagai hal khususnya ilmu pengetahuan demi masa depan yang lebih baik. ${ }^{12}$

\section{Al-Hadis}

Banyak hadis yang dapat dijadikan sebagai dasar pendidikan Islam di antaranya adalah sabda Nabi SAW yang artinya "Mencari ilmu

\footnotetext{
${ }^{11}$ Imam Muchlash ., Al-Qur'an Berbicara, (Surabaya:PustakaProgresif, 1996), hal 117.

${ }^{12}$ Imam Muchlash ., Al-Qur'an Berbicara, (Surabaya: PustakaProgresif1996), hal 118.
} 
merupakan kewajiban bagi setiap muslim laki-laki dan perempuan (HR. Muslim)" ${ }^{13}$ Dari hadis di atas dapat diambil kesimpulan bahwa Nabi saw memerintahkan agar umatnya menyelenggarakan pendidikan dan pengajaran.

Adapun berbicara tentang tujuan pendidikan Islam berarti berbicara tentang nilai-nilai ideal yang bercorak Islam. Hal ini mengandung makna bahwa tujuan pendidikan tersebut tidak lain adalah tujuan yang merealisasikan idealisme Islam. Sedangidealisme Islam itu sendiri pada hakekatnya adalah mengandung nilai perilaku manusia yang dijiwai atau didasari iman dan taqwa kepada Allah sebagai sumber kekuasan mutlak yang harus ditaati. $^{14}$

Pendidikan Islam ingin membentuk manusia yang menyadari dan melaksanakan tugas-tugas kekhalifahannya, dan memperkaya diri dengan khazanah ilmu pengetahuan tanpa mengenal batas, namun juga menyadari bahwa hakekat keseluruhan hidup dan pemilikan ilmu pengetahuan tersebut tetap bersumber dan bermuara pada Allah SWT sebagai Maha Pencipta dan Maha Mengetahui. Tujuan terakhir dari pendidikan Islam itu terletak dalam realisasi sikap penyerahan diri sepenuhny akepada Allah, baik secara perorangan, masyarakat maupun sebagai hamba yang berserah diri kepada Khaliqnya, ia adala hhamba yang berilmu pengetahuan dan beriman secara bulat, sesuai kehendak penciptanya untuk merealisasikancita-cita yang terkandung dalam kalimat ajaran Allah.

\section{Faktor Penunjang dan Penghambat Inovasi Pendidikan Islam}

Faktor penunjang terhadap inovasi pendidikan Islam yaitu: (a) Pokok-pokok pikiran tentang inovasi pendidikan Islam yang datang dari luar negeri, juga tidak kalah pentingnya dengan faktor-faktor yang lain. Karena, dengan pemikiran-pemikiran itulah, PAI melakukan perubahanperubahan materi pelajaran pendidikan Islam. (b) Perkembangan ilmu pengetahuan dan teknologi. Karena dengan banyaknya referensi yang bisa di dapatkan dari internet, maka akan memperkaya khasanah ilmu pengetahuan.

\footnotetext{
13 Shohih Muslim, Juz 2, t.t, h. 279

14 M. Arifin, Ilmu Pendidikan Islam (Suatu Tinjauan Teoritisdan Praktis Berdasarkan Pendekatan Interdisipliner), Bumi Aksara, Jakarta, 1994, h. 199
} 
Pembelajaran yang berbasis TI ini, banyak bertumpu pada aktifitas siswa, maka guru tidak lagi sebagai satu-satunya agent of information, melainkan lebih berperan sabagai penggerak, innovator, motivator, dinamisator, katalisator, penghubung, fasilitator, korektor, pengaya, dan evaluator.

Disamping adanya faktor penunjang dalam usaha mengadakan pembaharuan, tidak sedikit juga kita akan menghadapi faktor-faktor penghambat jalannya pembaharuan pendidikan Islam ini. Faktor penghambat yang ditemui diantaranya, yaitu: (a) Adanya pertentangan antara Ulama Muda dan Ulama Tua yang pada akhirnya melahirkan istilah Kaum Muda dan Kaum Tua. (b) Dikotomi atau diskrit, (c) Pembenturan umat Islam dengan pendidikan dan kemajuan Barat memunculkan kaum intelektual baru (cendekiawan sekuler).

Segala sesuatu hanya dilihat dari dua sisi yang berlawanan, seperti lakilaki dan perempuan, ada dan tidak ada, bulat dan tidak bulat, madrasah dan non madrasah, pendidikan keagamaan dan non keagamaan atau pendidikan agama dan pendidikan umum, demikian seterusnya.

Pandangan yang dikotomis tersebut pada giliran selanjutnya dikembangkan dalam melihat dan memandang aspek kehidupan dunia dan akhirat, kehidupan jasmani dan rohani sehingga pendidikan Islam hanya diletakkan pada aspek kehidupan akhirat saja atau kehidupan rohani saja.

Di dalam Islam padahal tidak pernah membedakan antara ilmuilmu agama dan ilmu umum (keduniaan), dan/atau tidak berpandangan dikotomis mengenai ilmu pengetahuan. Namun demikian, dalam realitas sejarahnya justru supremasi lebih diberikan pada ilmu-ilmu agama (al-ulum al-diniyah) sebagai jalan tol untuk menuju Tuhan. Sehingga menyebabkan kemunduran peradaban Islam serta keterbelakangan sains dan teknologi di dunia Islam. Hal ini terjadi bukan saja karena faktor dari luar tapi juga banyak dipengaruhi oleh faktor-faktor dari diri umat Islam itu sendiri, yang kurang peduli terhadap kebebasan penalaran intelektual dan kurang menghargai kajian-kajian rasional-empiris atau semangat pengembangan ilmiah dan filosofis.

Menurut Benda (dalam Sartono Kartodirjo, ed, 1981) sebagian besar kaum intelektual baru adalah hasil pendidikan Barat yang terlatih berpikir secara Barat. Dalam proses pendidikannya, mereka 
mengalami brain washing (cuci otak) dari hal-hal yang berbau Islam, sehingga mereka menjadi teralienasi (terasing) dari ajaran-ajaran Islam dan muslim sendiri. Bahkan terjadi gap antara kaum intelektual baru (sekuler) dengan intelektual lama (ulama), dan ulama dikonotasikan sebagai kaum sarungan yang hanya mengerti soal-soal keagamaan dan buta masalah keduniawian.

Sebagai implikasinya, pengembangan pendidikan Islam dalam arti pendidikan agama tersebut bergantung pada kemauan, kemampuan, dan political-will dari pembinanya dan sekaligus pimpinan dari lembaga pendidikan tersebut, terutama dalam membangun hubungan kerjasama dengan mata pelajaran (kuliah) lainnya. Hubungan (relasi) antara pendidikan agama dengan beberapa mata pelajaran (mata kuliah) lainnya dapat bersifat horizontal-lateral (independent), lateral-sekuensial, atau bahkan vertical linier.

Pengertian ini menggaris bawahi pentingnya kerangka pemikiran yang dibangun dari fundamental doctrins dan fundamental values yang tertuang dan terkandung dalam Al-Qur'an dan As-Sunnah shahihah sebagai sumber pokok, kemudian mau menerima kontribusi dari para ahli serta mempertimbangkan konteks historisnya. Karena itu, nilai Ilahi/agama/ wahyu di dudukkan sebagai sumber konsultasi yang bijak, sementara aspekaspek kehidupan lainnya didudukkan sebagai nilai insani yang mempunyai relasi horizontal-lateral atau lateral-sekuensial, tetapi harus berhubungan vertical-linier dengan nilai ilahi/agama.

Melalui upaya semacam itu maka sistem pendidikan Islam diharapkan dapat mengintegrasikan nilai-nilai ilmu pengetahuan, nilai-nilai agama dan etik, serta mampu melahirkan manusia-manusia yang menguasai ilmu pengetahuan dan teknologi, memiliki kematangan professional, dan sekaligus hidup di dalam nilai-nilai agama.

\section{Penutup}

Inovasi pendidikan dilakukan untuk memecahkan masalah-masalah kependidikan. Jadi, inovasi pendidikan adalah suatu ide, barang, metode, yang dirasakan atau diamati sebagai hal yang baru bagi hasil seseorang atau kelompok orang (masyarakat), baik berupa hasil inversi (penemuan baru) atau discoveri (baru ditemukan orang), yang digunakan untuk mencapai tujuan pendidikan atau untuk memecahkan masalah pendidikan. Namun 
dalam konteks pendidikan, Inovasi dapat berjalan dengan baik dan akan menghasilkan suatu hal yang positif dan lebih baik, jika para praktisi pendidikan memahami beberapa karakteristik dari inovasi pendidikan tersebut, karena karakteristik novasi pendidikan tersebut merupakan sifat yang melekat pada diri Inovasi pendidikan itu sendiri.

Model-model inovasi pendidikan dapat dikelompokkan 1)Invention (Penemuan), 2) Development (Pengembangan), 3) Diffusion (Penyebaran). Sedangkan karakteristik inovasi pendidikan adalah 1)Relative advantage, artinya relatif berguna dibandingkan dengan yang telah ada sebelumnya. 2) Compatibility, artinya apakah inovasi tersebut akan konsisten terhadap nilai-nilai, pengalaman dan kebutuhan para adopter. 3) Testability, artinya seberapa jauh inovasi tersebut bisa diujicobakan di sekolah-sekolah atau di lembaga pendidikan. 4) Observability, artinya apakah inovasi tersebut dapat diperlihatkan secara nyata hasilnya kepada para peserta didik dan Apakah kita bisa melihat variasi-variasi saat mengaplikasikan inovasi tersebut. 5) Complexity, artinya apakah guru-guru memerlukan pelatihan untuk mengaplikasikan inovasi tersebut dan apakah akan menambah tugas kerja guru.

Dari kelima karakteristik tersebut didapat peta konsep sebagai berikut: a) Keunggulan reatif, manfaat, menguntungkan pengguna, ekonomis, kepuasan pengguna, b) Kompleksitas, kerumitan, tingkat kesulitan, c) Kompatibilitas, kesesuaian dengan nilai, kesesuaian dengan pengalaman, kesesuaian dengan kebutuhan, d) Trialabilitas, dapat diuji coba, bergerak dan fakta. e) Observability, dapat diamati, terlihat, dapat dirasakan.

\section{Pustakan Acuan}

Arifin, M IlmuPendidikan Islam Suatu Tinjauan Teoritis dan Praktis Berdasarkan Pendekatan Interdisipliner, ,Jakarta:BumiAksara, 1994

Hasbullah, Dasar-dasar Ilmu Pendidikan: Umum dan Agama Islam,Jakarta: RajawaliPers, 2009

Ihsan, FuadDasarDasarPendidikan, Jakarta, RinekaCipta, 1995

Johnson, Laine B, Contexual Teaching \& Learning - Menjadikan Kegiatan BelajarMengajar Mengasyikkan dan Bermakna, Bandung: MLC, 2007 MadePidarta, LandasanKependidikan, Jakarta: PT Rineka Cipta, 2000 
Muchlash, Imam.,Al-Qur'an Berbicara, , Surabaya: PustakaProgresif, 1996 Salahuddin, Anas, Filsafat Pendidikan, Bandung: Pustaka Setia, 2011

Salam, Burhanuddin, Pengantar Pedagogik: Dasar-Dasar Ilmu Mendidik, Jakarta: Rineka Cipta, 1997

Sa'ud, Udin Syaefudin, Inovasi Pendidikan, Bandung: Alvabeta, 2010

Shohih Muslim, Juz 2, t.t

Wijaya, Cece, Upaya Pembahruan dalam Pendidikan Dan Pengajaran, Bandung: Remaja Rosdakarya, 1992 